Published in final edited form as:

Semin Hematol. 2009 January ; 46(1): 100-106. doi:10.1053/j.seminhematol.2008.09.001.

\title{
MINIMAL RESIDUAL DISEASE IN ACUTE LYMPHOBLASTIC LEUKEMIA
}

\author{
Dario Campana \\ Departments of Oncology and Pathology, St. Jude Children's Research Hospital; and Department \\ of Pediatric, University of Tennessee Health Science Center, Memphis, TN
}

\section{Abstract}

In patients with acute lymphoblastic leukemia (ALL), monitoring of minimal residual disease (MRD) offers a way to precisely assess early treatment response and detect relapse. Established methods to study MRD are flow cytometric detection of abnormal immunophenotypes, polymerase chain reaction (PCR) amplification of antigen-receptor genes, and PCR amplification of fusion transcripts. The strong correlation between MRD levels and risk of relapse in childhood ALL is well established; studies in adult patients also support its prognostic value. Hence, results of MRD studies can be used to select treatment intensity and duration, and estimate the optimal timing for hematopoietic stem cell transplantation. Practical issues in the implementation of MRD assays in clinical studies include determining the most informative time point to study MRD, the levels of MRD that will trigger changes in treatment intensity, as well as the relative cost and informative power of different methodologies. The identification of new markers of leukemia and the use of increasingly refined assays should further facilitate routine monitoring of MRD and help clarifying the cellular and biologic features of leukemic cells that resist chemotherapy in vivo.

\section{Introduction}

Three independent studies published ten years ago conclusively demonstrated that minimal residual disease (MRD) is a powerful prognostic indicator in newly diagnosed childhood acute lymphoblastic leukemia (ALL). ${ }^{1-3}$ These studies represented the culmination of efforts of many investigators (reviewed in ${ }^{4}$ ), and stimulated the design of treatment protocols in which risk assignment was largely based on MRD measurements

Research to develop methods for detecting small numbers of leukemic cells had begun to intensify approximately two decades earlier. In 1980, Janossy and colleagues reported the use of antibody staining of terminal deoxynucleotidil transferase (TdT) to differentiate leukemic lymphoblasts from normal lymphocytes in the cerebrospinal fluid of patients with ALL; 5 a year later, they reported that anti-TdT in combination with an anti-T cell antibody could identify MRD in the bone marrow of patients with T-ALL in morphologic remission. ${ }^{6}$ The advent of flow cytometers subsequently widened and improved the use of antibodies to identify leukemic cells. ${ }^{7-9}$ About the same time, polymerase chain reaction (PCR)-based methods to amplify fusion transcripts in ALL cells were developed, ${ }^{10,11}$ and the use of PCR amplification of antigen-receptor genes to track ALL cells was reported. ${ }^{12-15}$ Numerous studies that followed

Correspondence: D. Campana, M.D. Ph.D., Department of Oncology, St. Jude Children's Research Hospital, 262 Danny Thomas Place, Memphis TN 38105; Telephone 901-595 2528; FAX 901-595 5947; E-mail: dario.campana@ stjude.org.

Publisher's Disclaimer: This is a PDF file of an unedited manuscript that has been accepted for publication. As a service to our customers we are providing this early version of the manuscript. The manuscript will undergo copyediting, typesetting, and review of the resulting proof before it is published in its final citable form. Please note that during the production process errors may be discovered which could affect the content, and all legal disclaimers that apply to the journal pertain. 
(reviewed in 16,17 ) refined and expanded this pioneering work, ultimately producing methods that are sufficiently sensitive, precise and reliable to guide treatment decisions.

\section{Clinical applications of MRD studies}

\section{Selection of patients for treatment intensification}

MRD studies revealed that many patients who achieve morphologic remission harbored residual disease, a finding that is associated with a higher risk of relapse. ${ }^{16,17}$ MRD can also identify patients with a higher risk of relapse among those with specific ALL subtypes defined by presenting features. ${ }^{18-20}$ Moreover, among patients with first-relapse ALL who achieve a second remission, MRD predicts a significantly worse outcome. ${ }^{21,22}$ Hence, the most immediate application of MRD testing is the identification of patients who are candidates for treatment intensification.

Levels of MRD are proportional to the risk of relapse. We found that MRD equal or greater than $1 \%$ at the end of remission induction therapy (in patients who were morphologically in remission) associated with a dismal outcome, ${ }^{18}$ prompting the design of protocols which recommended transplant in first remission for these patients. ${ }^{23}$ Investigators of the International Berlin-Frankfurt-Munster (I-BFM) Study Group found that patients with MRD levels of $0.1 \%$ or higher on both day 33 and day 78 of treatment had a relapse rate of $75 \%, 3$ prompting treatment intensification for this group of patients. ${ }^{24}$

\section{Selection of patients for treatment deintensification}

MRD studies revealed that remission induction therapy can produce dramatic leukemia cytoreduction and undetectable MRD after only 2-3 weeks of therapy in a proportion of patients. In a recent analysis of 402 patients with B-lineage ALL, we found that $183(45.5 \%)$ were MRD-negative on day 19 , defined as having $<0.01 \%$ leukemic cells in bone marrow. ${ }^{25}$

Patients with early clearance of leukemic cells typically remain MRD-negative, and their prognosis is excellent with current treatment protocols. ${ }^{26,27}$ Should treatment deintensification be considered for these patients? One argument against is that early MRDnegativity might be a good prognostic feature only in the context of intensive therapy. Thus, if therapy is deintensified, the risk of relapse of MRD-negative patients might increase significantly. The counterargument is that some patients with ALL must be curable with less intensive therapy than in prevailing in contemporary regimens. Indeed, $36 \%$ of patients were cured in St Jude treatment protocols from 1967 to 1979 (much less intense than today's regimens), and 53\% in those from 1979 to 1983 (including limited treatment intensification). 28 Moreover, in a study where all treatment stopped 1 year after diagnosis, the mean 5-year event-free survival approached $60 \% .{ }^{29}$ If some forms of ALL can be cured with less intensive and/or shorter therapy, an excellent response to initial therapy should be a feature of these leukemias. The best way to apply MRD results for treatment deintensification has not yet been defined. However, this option appears to be especially attractive in when intensive therapy confers a high risk of serious toxicities (as at centers with limited resources, or in older adult patients), and the potential benefits of treatment deintensification might outweigh the risk of relapse.

\section{MRD postremission and timing of hematopoietic stem cell transplantation}

In patients who attain first or second remission, sequential MRD monitoring may identify relapse before its detection by morphology or cytogenetics. Sequential MRD monitoring is particularly useful in those patients who are in remission but who remain MRD-positive at the end of remission induction therapy. Conversion to MRD-negativity is associated with a favorable outcome, while persistence or increase in levels of MRD carries a high hazard of 
relapse. ${ }^{18}$ Vigorous lympho-hematopoietic regeneration mimicking relapse may occur in patients who are not compliant with post-remission therapy. In these cases, MRD studies can quickly clarify the nature of the morphologically suspect cells.

Based on the observation that detection of MRD before allogeneic hematopoietic stem cell transplantation (HSCT) is associated with an increase risk of relapse post-HSCT, ${ }^{30-35} \mathrm{MRD}$ assays increasingly are being used to select the timing of transplant. Thus, patients with MRDpositivity who are candidates for transplant may receive additional courses of chemotherapy in efforts to reduce the levels of MRD, possibly below detection threshold, before HSCT. After transplant, detection of MRD can serve as an indicator for decreasing immunosuppressive therapy and/or administering donor lymphocyte infusions.

\section{Methodologies to detect MRD}

Leukemic cells differ from normal hematopoietic cells in several genetic and cellular features.

36 One leukemia-associated property is the expression of abnormal cell marker profiles which can be detected with flow cytometry. ${ }^{17}$ With rare exceptions, leukemic lymphoblasts have immunophenotypes sufficiently distinct to allow the detection of 1 leukemic cells among 10,000 normal cells $(0.01 \%){ }^{27,37}$ Another leukemia-associated characteristic is the clonal rearrangement of immunoglobulin (IG) and T-cell receptor (TCR) genes This rearrangement results in unique molecular signatures which can be detected by PCR in most cases, with a sensitivity of $0.01 \%$ to $0.001 \% .38$ A third leukemia-associated feature is represented by chromosomal abnormalities and their corresponding gene fusions, such as BCR-ABL, MLL$A F 4, E 2 A-P B X 1$, and TEL-AML1. ${ }^{39,40}$ Less than one-third of patients with ALL have leukemic cells with genetic abnormalities that can be studied with the typical assays performed in molecular pathology laboratories, allowing the detection of MRD with a sensitivity ranging from $0.1 \%$ to $0.001 \%$.

Strengths of flow cytometry-based assays include accurate quantification of MRD and the capacity to examine the status of normal hematopoietic cell maturation simultaneously. Accurate quantification of MRD is also a property of PCR amplification of antigen-receptor genes, in addition to its high sensitivity. A strength of PCR amplification of fusion transcripts is the stable association between the molecular abnormality and the leukemic clone, regardless of cellular changes caused by therapy or clonal selection.

MRD assays are complex and necessitate considerable expertise to be executed well. For example, flow cytometric studies require specific knowledge of the immunophenotypic profiles of bone marrow and peripheral blood under a variety of conditions, and experience in selecting the best markers to use in each case. ${ }^{37}$ The interpretation of the data should take into account the fact that chemotherapy may alter the phenotype. ${ }^{2,41}$ PCR amplification of antigenreceptor genes also requires considerable expertise. Careful consideration must be given to the presence of minor clones, which might be undetected at diagnosis and can that become predominant during the course of the disease. ${ }^{42,43}$ Targeting two or more different rearrangements has been recommended to avert this problem, ${ }^{44}$ but multiple sensitive probes are not identifiable in approximately $30 \%$ of cases. ${ }^{24,45}$ Finally, a pitfall of PCR amplification of fusion transcripts is imprecise quantification of MRD, as the number of transcripts per leukemic cell varies from patient to patient with the same genetic subtype of ALL and might also be affected by therapy. 40

\section{Clinically informative MRD levels}

The $0.01 \%$ threshold is commonly used to define MRD positivity, simply because this represents the typical limit of detection for routine flow cytometric and molecular assays. Nevertheless, it is possible to achieve a routine sensitivity of $0.001 \%$ by PCR in clinical 
samples. With improvements in technology, it is likely that such threshold could also soon be achieved by flow cytometry. The current $0.01 \%$ threshold has proven to be clinically informative. For example, we found that patients who had MRD of $0.01 \%$ or higher in bone marrow at any time point during treatment had a significantly higher risk of relapse. $2,18,27$ Likewise, the Children's Oncology Group (COG) found that the presence of MRD $(0.01 \%$ or higher) on day 29 predicted a poorer outcome and was the strongest prognostic indicator. ${ }^{46}$ Depending on the protocol and on the time point at which MRD is examined, other threshold levels can also be informative. Cave et al. ${ }^{1}$ found a cut-off level of $0.1 \%$ at the end of remission induction and thereafter to be particularly informative. Investigators of the I-BFM Study Group reported that patients with $0.1 \%$ or higher MRD on days 33 and 78 had a particularly high relapse rate $; 3,24$ those of the Austrian BFM group also reported that the cut-off level of $0.1 \%$ on day 33 was particularly informative. ${ }^{47}$ For the Dana-Farber Cancer Institute ALL Consortium, an MRD threshold of $0.1 \%$ best predicted relapse hazard. ${ }^{48}$

Flow cytometry and PCR amplification of IGH and TCR genes should yield similar estimates whenever MRD is $0.01 \%$ or higher. ${ }^{49,50}$ Whether the results of these methods coincide with those of PCR amplification of fusion transcripts is not yet established. It is possible that in some cases preleukemic clones 51 might be detected by PCR targeting of the fusion transcript but remain undetected by flow cytometric methods or PCR targeting antigen receptor genes.

\section{Prognostic significance of MRD in adult ALL}

There is increasing evidence that MRD also has strong prognostic significance in adult patients with ALL. In 85 patients with Philadelphia $(\mathrm{Ph})$ chromosome-negative B-lineage ALL, the presence of MRD correlated with an adverse clinical outcome, particularly when measured 35 months after induction therapy. ${ }^{52}$ In 196 standard-risk patients, Bruggeman et al. ${ }^{53}$ identified $10 \%$ of patients with a rapid MRD decline to lower than $0.01 \%$ on day 11 and day 24 (low-risk group) who had a 3-year relapse rate of $0 \% ; 23 \%$ of patients had MRD $0.01 \%$ or higher until week 16 (high-risk) and had a relapse rate of $94 \%$; the remaining patients (intermediate-risk) had a relapse rate of $47 \%$. The same group also reported a prospective analysis of post-consolidation samples in 105 patients who were in hematologic remission, had completed first-year chemotherapy, and had tested MRD-negative prior to enrollment in the study. Twenty-eight patients converted to MRD positivity and 17 of these had relapsed, with a median time from molecular to clinical relapse of 9.5 months. By contrast, only 5 of the 77 continuously MRD-negative patients had relapsed. ${ }^{54} \mathrm{~A}$ recent study assessed MRD in 116 patients with Ph-negative ALL and indicated that MRD equal or greater than $0.1 \%$ after induction was an independent predictor for relapse in both standard- and high-risk groups. ${ }^{55}$

MRD monitoring of BCR-ABL fusion transcripts predicted the outcome of allogeneic or autologous HSCT in adult patients with Ph-positive ALL. ${ }^{56}$ In 27 patients who received imatinib upon detection of MRD after HSCT, BCR-ABL transcripts became undetectable in 14, after a median of 1.5 months. ${ }^{57}$ These patients remained in remission for the duration of imatinib treatment; 3 relapsed after imatinib was discontinued. By contrast, 12 of the 13 patients who failed to achieve molecular remission relapsed. MRD status after allogeneic bone marrow transplantation was also found to be an important predictor of outcome in adults with $\mathrm{Ph}$ negative ALL, ${ }^{52}$ while MRD detected in bone marrow samples taken prospectively from patients with ALL before initiating the conditioning regimen was a significant predictor of outcome. ${ }^{58}$ In 43 adult patients with ALL undergoing HSCT, the cumulative incidence of relapse at 36 months was $0 \%$ for the 12 patients who were MRD-negative before transplantation compared to $46 \%$ for MRD-positive patients. 59 


\section{Practical issues for clinical application}

What are the most informative time points for MRD testing? MRD measurements during remission induction therapy are highly informative in childhood ALL. In general, measurements during remission induction therapy (typically 2 weeks after diagnosis) provide an early identification of good responders and of very poor responders, which can be further refined by assessing MRD at the end of induction therapy and during the early phases of continuation therapy. At St Jude Children's Research Hospital, we currently use MRD on day 15 and day 42 for treatment assignment. Patients with MRD of $1 \%$ of higher on day 15 receive intensified remission induction therapy; further intensification is reserved for patients with $5 \%$ of more leukemic cells. Conversely, patients with undetectable MRD $(<0.01 \%)$ on day 15 receive a slightly less intensive reinduction therapy and lower cumulative doses of anthracyclin. Patients with standard-risk ALL who have MRD of $0.01 \%$ or higher on day 42 are reclassified as high-risk. Any patient with MRD of $1 \%$ or higher at this time point is a candidate for HSCT in first remission.

What is the best method to study MRD? Both flow cytometry and PCR amplification of antigenreceptor genes yield similar results when MRD is at levels of $0.01 \%$ or above, ${ }^{49,50}$ and both methods can produce MRD estimates within 24 hours of sample collection. In our experience, the overall cost of the two methods is similar but others have estimated PCR to be more expensive. ${ }^{60}$ Flow cytometry is more likely to be readily available (flow cytometers and methods for leukemia immunophenotyping are used at virtually every cancer center) and, for studies at early time points during therapy, like day 15 , has an advantage over PCR, as the development of a patient-tailored PCR assay typically requires more than two weeks. PCR might be preferable for studies post-HSCT or at the end of therapy because of its high sensitivity. Eventually, the type of expert laboratory available to a cancer center or a cooperative group could be the most important factor in determining which method should be used.

Can MRD be determined in peripheral blood? In patients with B-lineage ALL, MRD is usually present at higher levels in bone marrow than in peripheral blood. ${ }^{61-63}$ Such is not the case in T-ALL, where MRD levels in peripheral blood are similar to those in bone marrow. ${ }^{62,63} \mathrm{In}$ these patients, sequential MRD testing can be performed in blood, which is our current practice.

\section{Concluding remarks}

Molecular assessment of treatment response is increasingly used to guide therapeutic decisions. MRD measurements can also be used to identify molecular features of leukemic cells associated with treatment response in vivo. To this end, comparisons of gene expression profiles of lymphoblasts in patients with and without MRD allowed the identification of several prognostic genes. ${ }^{64-66}$

MRD studies are relatively expensive in comparison to other diagnostic assays, but considering their potential clinical benefits, the investment appears justified. As was eloquently argued by Goulden et al., ${ }^{60}$ MRD analysis should pay for itself. To widen the use of MRD, it is important to further simplify the relevant technologies. To this end, we modified flow cytometry to study MRD in patients with B-lineage ALL during remission induction therapy. ${ }^{67}$ When applied to samples collected on day 19 of treatment, the results of the simplified assay correlated well with those of the more complex flow cytometric assay and those of PCR amplification of antigen-receptor genes. This assay is well suited for measurements of early treatment response. Because of its low costs and simplicity, it should facilitate the implementation of MRD measurements in centers with limited resources. 
The identification of new markers and the further refinement of techniques should also increase applicability of MRD testing. MRD assays provide new opportunities for renewing the classical design of phase II studies, by using changes in MRD levels to rapidly identify the most effective new anti-leukemic agents. Finally, the direct probing of the biology of MRD cells and further understanding of the features that distinguish leukemic cells that do not respond to treatment from those that respond should provide clues to improve effectiveness of therapy.

\section{Acknowledgements}

This work was supported by grants CA60419 and CA21765 from the National Cancer Institute, and by the American Lebanese Syrian Associated Charities (ALSAC)

\section{References}

1. Cave H, van der Werff ten Bosch J, Suciu S, Guidal C, Waterkeyn C, Otten J, et al. Clinical significance of minimal residual disease in childhood acute lymphoblastic leukemia. European Organization for Research and Treatment of Cancer--Childhood Leukemia Cooperative Group. N Engl J Med 1998;339:591-598. [PubMed: 9718378]

2. Coustan-Smith E, Behm FG, Sanchez J, Boyett JM, Hancock ML, Raimondi SC, et al. Immunological detection of minimal residual disease in children with acute lymphoblastic leukaemia. Lancet 1998;351:550-554. [PubMed: 9492773]

3. van Dongen JJ, Seriu T, Panzer-Grumayer ER, Biondi A, Pongers-Willemse MJ, Corral L, et al. Prognostic value of minimal residual disease in acute lymphoblastic leukaemia in childhood. Lancet 1998;352:1731-1738. [PubMed: 9848348]

4. Campana D, Pui CH. Detection of minimal residual disease in acute leukemia: methodologic advances and clinical significance. Blood 1995;85:1416-1434. [PubMed: 7888664]

5. Bradstock KF, Papageorgiou ES, Janossy G, Hoffbrand AV, Willoughby ML, Roberts PD, et al. Detection of leukaemic lymphoblasts in CSF by immunofluorescence for terminal transferase. Lancet 1:1144-1980. [PubMed: 6154853]

6. Bradstock KF, Janossy G, Tidman N, Papageorgiou ES, Prentice HG, Willoughby M, et al. Immunological monitoring of residual disease in treated thymic acute lymphoblastic leukaemia. Leuk Res 1981;5:301-309. [PubMed: 7026903]

7. Hurwitz CA, Loken MR, Graham ML, Karp JE, Borowitz MJ, Pullen DJ, et al. Asynchronous antigen expression in B lineage acute lymphoblastic leukemia. Blood 1988;72:299-307. [PubMed: 3291983]

8. Terstappen LW, Loken MR. Myeloid cell differentiation in normal bone marrow and acute myeloid leukemia assessed by multi-dimensional flow cytometry. Anal Cell Pathol 1990;2:229-240. [PubMed: 1703434]

9. Campana D, Coustan-Smith E, Janossy G. The immunologic detection of minimal residual disease in acute leukemia. Blood 1990;76:163-171. [PubMed: 1973061]

10. Kawasaki ES, Clark SS, Coyne MY, Smith SD, Champlin R, Witte ON, et al. Diagnosis of chronic myeloid and acute lymphocytic leukemias by detection of leukemia-specific mRNA sequences amplified in vitro. Proc Natl Acad Sci USA 1988;85:5698-5702. [PubMed: 3165197]

11. Hermans A, Gow J, Selleri L, von Lindern M, Hagemeijer A, Wiedemann LM, et al. bcr-abl oncogene activation in Philadelphia chromosome-positive acute lymphoblastic leukemia. Leukemia 1988;2:628-633. [PubMed: 3172839]

12. d'Auriol L, MacIntyre E, Galibert F, Sigaux F. In vitro amplification of T cell gamma gene rearrangements: a new tool for the assessment of minimal residual disease in acute lymphoblastic leukemias. Leukemia 1989;3:155-158. [PubMed: 2536129]

13. Hansen-Hagge TE, Yokota S, Bartram CR. Detection of minimal residual disease in acute lymphoblastic leukemia by in vitro amplification of rearranged T-cell receptor delta chain sequences. Blood 1989;74:1762-1767. [PubMed: 2676018]

14. Yamada M, Hudson S, Tournay O, Bittenbender S, Shane SS, Lange B, et al. Detection of minimal disease in hematopoietic malignancies of the B-cell lineage by using third-complementarity- 
determining region (CDR-III)-specific probes. Proc Natl Acad Sci USA 1989;86:5123-5127. [PubMed: 2500663]

15. Brisco MJ, Condon J, Hughes E, Neoh SH, Sykes PJ, Seshadri R, et al. Outcome prediction in childhood acute lymphoblastic leukaemia by molecular quantification of residual disease at the end of induction. Lancet 1994;343:196-200. [PubMed: 7904666]

16. Szczepanski T, Orfao A, van der Velden VH, San Miguel JF, van Dongen JJ. Minimal residual disease in leukaemia patients. Lancet Oncology 2001;2:409-417. [PubMed: 11905735]

17. Campana D. Determination of minimal residual disease in leukemia patients. Br J Haematol 2003;121:823-838. [PubMed: 12786792]

18. Coustan-Smith E, Sancho J, Hancock ML, Boyett JM, Behm FG, Raimondi SC, et al. Clinical importance of minimal residual disease in childhood acute lymphoblastic leukemia. Blood 2000;96:2691-2696. [PubMed: 11023499]

19. Biondi A, Valsecchi MG, Seriu T, d'Aniello E, Willemse MJ, Fasching K, et al. Molecular detection of minimal residual disease is a strong predictive factor of relapse in childhood B-lineage acute lymphoblastic leukemia with medium risk features. A case control study of the International BFM study group. Leukemia 2000;14:1939-1943. [PubMed: 11069029]

20. Attarbaschi A, Mann G, Panzer-Grumayer R, Rottgers S, Steiner M, Konig M, et al. Minimal residual disease values discriminate between low and high relapse risk in children with B-cell precursor acute lymphoblastic leukemia and an intrachromosomal amplification of chromosome 21: the Austrian and German acute lymphoblastic leukemia Berlin-Frankfurt-Munster (ALL-BFM) trials. J Clin Oncol 2008;26:3046-3050. [PubMed: 18565891]

21. Eckert C, Biondi A, Seeger K, Cazzaniga G, Hartmann R, Beyermann B, et al. Prognostic value of minimal residual disease in relapsed childhood acute lymphoblastic leukaemia. Lancet 2001;358:1239-1241. [PubMed: 11675066]

22. Coustan-Smith E, Gajjar A, Hijiya N, Razzouk BI, Ribeiro RC, Rivera GK, et al. Clinical significance of minimal residual disease in childhood acute lymphoblastic leukemia after first relapse. Leukemia 2004;18:499-504. [PubMed: 14981525]

23. Pui CH, Evans WE. Treatment of acute lymphoblastic leukemia. N Engl J Med 2006;354:166-178. [PubMed: 16407512]

24. Flohr T, Schrauder A, Cazzaniga G, Panzer-Grumayer R, van der Velden V, Fischer S, et al. Minimal residual disease-directed risk stratification using real-time quantitative PCR analysis of immunoglobulin and T-cell receptor gene rearrangements in the international multicenter trial AIEOP-BFM ALL 2000 for childhood acute lymphoblastic leukemia. Leukemia 2008;22:771-782. [PubMed: 18239620]

25. Campana D. Molecular determinants of treatment response in acute lymphoblastic leukemia. Hematology (Am Soc Hematol Educ Program). 2008In press

26. Panzer-Grumayer ER, Schneider M, Panzer S, Fasching K, Gadner H. Rapid molecular response during early induction chemotherapy predicts a good outcome in childhood acute lymphoblastic leukemia. Blood 2000;95:790-794. [PubMed: 10648387]

27. Coustan-Smith E, Sancho J, Behm FG, Hancock ML, Razzouk BI, Ribeiro RC, et al. Prognostic importance of measuring early clearance of leukemic cells by flow cytometry in childhood acute lymphoblastic leukemia. Blood 2002;100:52-58. [PubMed: 12070008]

28. Rivera GK, Pinkel D, Simone JV, Hancock ML, Crist WM. Treatment of acute lymphoblastic leukemia. 30 years' experience at St Jude Children's Research Hospital. N Engl J Med 1993;329:1289-1295. [PubMed: 8413409]

29. Toyoda Y, Manabe A, Tsuchida M, Hanada R, Ikuta K, Okimoto Y, et al. Six months of maintenance chemotherapy after intensified treatment for acute lymphoblastic leukemia of childhood. J Clin Oncol 2000;18:1508-1516. [PubMed: 10735899]

30. Knechtli CJC, Goulden NJ, Hancock JP, Grandage VLG, Harris EL, Garland RJ, et al. Minimal residual disease status before allogeneic bone marrow transplantation is an important determinant of successful outcome for children and adolescents with acute lymphoblastic leukemia. Blood 1998;92:4072-4079. [PubMed: 9834212]

31. van der Velden V, Joosten SA, Willemse MJ, Van Wering ER, Lankester AW, van Dongen JJ, et al. Real-time quantitative PCR for detection of minimal residual disease before allogeneic stem cell 
transplantation predicts outcome in children with acute lymphoblastic leukemia. Leukemia 2001;15:1485-1487. [PubMed: 11516112]

32. Bader P, Hancock J, Kreyenberg H, Goulden NJ, Niethammer D, Oakhill A, et al. Minimal residual disease (MRD) status prior to allogeneic stem cell transplantation is a powerful predictor for posttransplant outcome in children with ALL. Leukemia 2002;16:1668-1672. [PubMed: 12200679]

33. Uzunel M, Mattsson J, Jaksch M, Remberger M, Ringden O. The significance of graft-versus-host disease and pretransplantation minimal residual disease status to outcome after allogeneic stem cell transplantation in patients with acute lymphoblastic leukemia. Blood 2001;98:1982-1984. [PubMed: 11535539]

34. Krejci O, van der Velden V, Bader P, Kreyenberg H, Goulden N, Hancock J, et al. Level of minimal residual disease prior to haematopoietic stem cell transplantation predicts prognosis in paediatric patients with acute lymphoblastic leukaemia: a report of the Pre-BMT MRD Study Group. Bone Marrow Transplant 2003;32:849-851. [PubMed: 14520434]

35. Goulden N, Bader P, van der Velden V, Moppett J, Schilham M, Masden HO, et al. Minimal residual disease prior to stem cell transplant for childhood acute lymphoblastic leukaemia. Br J Haematol 2003;122:24-29. [PubMed: 12823342]

36. Campana D. Status of minimal residual disease testing in childhood haematological malignancies. Br J Haematol. 2008in press

37. Campana D, Coustan-Smith E. Detection of minimal residual disease in acute leukemia by flow cytometry. Cytometry 1999;38:139-152. [PubMed: 10440852]

38. van der Velden V, Hochhaus A, Cazzaniga G, Szczepanski T, Gabert J, van Dongen JJ. Detection of minimal residual disease in hematologic malignancies by real-time quantitative PCR: principles, approaches, and laboratory aspects. Leukemia 2003;17:1013-1034. [PubMed: 12764363]

39. van Dongen JJ, Macintyre EA, Gabert JA, Delabesse E, Rossi V, Saglio G, et al. Standardized RTPCR analysis of fusion gene transcripts from chromosome aberrations in acute leukemia for detection of minimal residual disease. Report of the BIOMED-1 Concerted Action: investigation of minimal residual disease in acute leukemia. Leukemia 1999;13:1901-1928. [PubMed: 10602411]

40. Gabert J, Beillard E, van der Velden V, Bi W, Grimwade D, Pallisgaard N, et al. Standardization and quality control studies of 'real-time' quantitative reverse transcriptase polymerase chain reaction of fusion gene transcripts for residual disease detection in leukemia - a Europe Against Cancer program. Leukemia 2003;17:2318-2357. [PubMed: 14562125]

41. Gaipa G, Basso G, Maglia O, Leoni V, Faini A, Cazzaniga G, et al. Drug-induced immunophenotypic modulation in childhood ALL: implications for minimal residual disease detection. Leukemia 2005;19:49-56. [PubMed: 15538405]

42. Szczepanski T, Willemse MJ, Brinkhof B, Van Wering ER, van der Burg M, van Dongen JJ. Comparative analysis of Ig and TCR gene rearrangements at diagnosis and at relapse of childhood precursor-B-ALL provides improved strategies for selection of stable PCR targets for monitoring of minimal residual disease. Blood 2002;99:2315-2323. [PubMed: 11895762]

43. van der Velden V, Bruggemann M, Hoogeveen PG, de Bie M, Hart PG, Raff T, et al. TCRB gene rearrangements in childhood and adult precursor-B-ALL: frequency, applicability as MRD-PCR target, and stability between diagnosis and relapse. Leukemia 2004;18:1971-1980. [PubMed: 15470492]

44. van der Velden V, Cazzaniga G, Schrauder A, Hancock J, Bader P, Panzer-Grumayer ER, et al. Analysis of minimal residual disease by Ig/TCR gene rearrangements: guidelines for interpretation of real-time quantitative PCR data. Leukemia 2007;21:604-611. [PubMed: 17287850]

45. Pongers-Willemse MJ, Seriu T, Stolz F, d'Aniello E, Gameiro P, Pisa P, et al. Primers and protocols for standardized detection of minimal residual disease in acute lymphoblastic leukemia using immunoglobulin and T cell receptor gene rearrangements and TAL1 deletions as PCR targets. Leukemia 1999;13:110-118. [PubMed: 10049045]

46. Borowitz MJ, Devidas M, Hunger SP, Bowman WP, Carroll AJ, Carroll WL, et al. Clinical significance of minimal residual disease in childhood acute lymphoblastic leukemia and its relationship to other prognostic factors. a Children's Oncology Group study. Blood. 2008in press 
47. Dworzak MN, Froschl G, Printz D, Mann G, Potschger U, Muhlegger N, et al. Prognostic significance and modalities of flow cytometric minimal residual disease detection in childhood acute lymphoblastic leukemia. Blood 2002;99:1952-1958. [PubMed: 11877265]

48. Zhou J, Goldwasser MA, Li A, Dahlberg SE, Neuberg D, Wang H, et al. Quantitative analysis of minimal residual disease predicts relapse in children with B-lineage acute lymphoblastic leukemia in DFCI ALL Consortium Protocol 95-01. Blood 2007;110:1607-1611. [PubMed: 17485550]

49. Neale GA, Coustan-Smith E, Stow P, Pan Q, Chen X, Pui CH, et al. Comparative analysis of flow cytometry and polymerase chain reaction for the detection of minimal residual disease in childhood acute lymphoblastic leukemia. Leukemia 2004;18:934-938. [PubMed: 15029212]

50. Kerst G, Kreyenberg H, Roth C, Well C, Dietz K, Coustan-Smith E, et al. Concurrent detection of minimal residual disease (MRD) in childhood acute lymphoblastic leukaemia by flow cytometry and real-time PCR. Br J Haematol 2005;128:774-782. [PubMed: 15755280]

51. Hong D, Gupta R, Ancliff P, Atzberger A, Brown J, Soneji S, et al. Initiating and cancer-propagating cells in TEL-AML1-associated childhood leukemia. Science 2008;319:336-339. [PubMed: 18202291]

52. Mortuza FY, Papaioannou M, Moreira IM, Coyle LA, Gameiro P, Gandini D, et al. Minimal residual disease tests provide an independent predictor of clinical outcome in adult acute lymphoblastic leukemia. J Clin Oncol 2002;20:1094-1104. [PubMed: 11844835]

53. Bruggemann M, Raff T, Flohr T, Gokbuget N, Nakao M, Droese J, et al. Clinical significance of minimal residual disease quantification in adult patients with standard-risk acute lymphoblastic leukemia. Blood 2006;107:1116-1123. [PubMed: 16195338]

54. Raff T, Gokbuget N, Luschen S, Reutzel R, Ritgen M, Irmer S, et al. Molecular relapse in adult standard-risk ALL patients detected by prospective MRD monitoring during and after maintenance treatment: data from the GMALL 06/99 and 07/03 trials. Blood 2007;109:910-915. [PubMed: 17023577]

55. Holowiecki J, Krawczyk-Kulis M, Giebel S, Jagoda K, Stella-Holowiecka B, Piatkowska-Jakubas B, et al. Status of minimal residual disease after induction predicts outcome in both standard and highrisk Ph-negative adult acute lymphoblastic leukaemia. The Polish Adult Leukemia Group ALL 4-2002 MRD Study. Br J Haematol. 2008in press

56. Radich J, Gehly G, Lee A, Avery R, Bryant E, Edmands S, et al. Detection of bcr-abl transcripts in Philadelphia chromosome-positive acute lymphoblastic leukemia after marrow transplantation. Blood 1997;89:2602-2609. [PubMed: 9116308]

57. Wassmann B, Pfeifer H, Stadler M, Bornhauser M, Bug G, Scheuring UJ, et al. Early molecular response to posttransplantation imatinib determines outcome in MRD+ Philadelphia-positive acute lymphoblastic leukemia (Ph+ ALL). Blood 2005;106:458-463. [PubMed: 15817679]

58. Sanchez J, Serrano J, Gomez P, Martinez F, Martin C, Madero L, et al. Clinical value of immunological monitoring of minimal residual disease in acute lymphoblastic leukaemia after allogeneic transplantation. Br J Haematol 2002;116:686-694. [PubMed: 11849234]

59. Spinelli O, Peruta B, Tosi M, Guerini V, Salvi A, Zanotti MC, et al. Clearance of minimal residual disease after allogeneic stem cell transplantation and the prediction of the clinical outcome of adult patients with high-risk acute lymphoblastic leukemia. Haematologica 2007;92:612-618. [PubMed: 17488684]

60. Goulden N, Oakhill A, Steward C. Practical application of minimal residual disease assessment in childhood acute lymphoblastic leukaemia annotation. Br J Haematol 2001;112:275-281. [PubMed: 11167819]

61. Brisco MJ, Sykes PJ, Hughes E, Dolman G, Neoh SH, Peng LM, et al. Monitoring minimal residual disease in peripheral blood in B-lineage acute lymphoblastic leukaemia. Br J Haematol 1997;99:314319. [PubMed: 9375747]

62. Coustan-Smith E, Sancho J, Hancock ML, Razzouk BI, Ribeiro RC, Rivera GK, et al. Use of peripheral blood instead of bone marrow to monitor residual disease in children with acute lymphoblastic leukemia. Blood 2002;100:2399-2402. [PubMed: 12239148]

63. van der Velden V, Jacobs DC, Wijkhuijs AJ, Comans-Bitter WM, Willemse MJ, Hahlen K, et al. Minimal residual disease levels in bone marrow and peripheral blood are comparable in children with 
T cell acute lymphoblastic leukemia (ALL), but not in precursor-B-ALL. Leukemia 2002;16:14321436. [PubMed: 12145681]

64. Cario G, Stanulla M, Fine BM, Teuffel O, Neuhoff NV, Schrauder A, et al. Distinct gene expression profiles determine molecular treatment response in childhood acute lymphoblastic leukemia. Blood 2005;105:821-826. [PubMed: 15388585]

65. Flotho C, Coustan-Smith E, Pei D, Iwamoto S, Song G, Cheng C, et al. Genes contributing to minimal residual disease in childhood acute lymphoblastic leukemia: prognostic significance of CASP8AP2. Blood 2006;108:1050-1057. [PubMed: 16627760]

66. Flotho C, Coustan-Smith E, Pei D, Cheng C, Song G, Pui CH, et al. A set of genes that regulate cell proliferation predicts treatment outcome in childhood acute lymphoblastic leukemia. Blood 2007;110:1271-1277. [PubMed: 17456722]

67. Coustan-Smith E, Ribeiro RC, Stow P, Zhou Y, Pui CH, Rivera GK, et al. A simplified flow cytometric assay identifies children with acute lymphoblastic leukemia who have a superior clinical outcome. Blood 2006;108:97-102. [PubMed: 16537802] 